\title{
Economic Impact of Gastrointestinal Helminth Infections on Milk Production in Swamp Buffalo
}

\author{
Meena Das ${ }^{1 *}$ and Dillip Kumar Deka ${ }^{2}$ \\ ${ }^{1}$ Division of Animal and Fishery Science, ICAR Research Complex for NEH Region, Umiam, Meghalaya, INDIA \\ ${ }^{2}$ Department of Parasitology, College of Veterinary Science, AAU, Khanapara, Assam, INDIA \\ "Corresponding author: M Das; E-mail:meenad3@gmail.com
}

Received: 14 July, 2021

Revised: 25 Aug., 2021

Accepted: 03 Sept., 2021

\begin{abstract}
The objective of the present study was to assess the economic impact of gastrointestinal helminth infections on milk production in naturally infected swamp buffaloes of Guwahati, Assam, India. Selected animals were divided into three groups (I, II and III) having 10 animals in each group. Animals of group I (Amphistome sp.+ Strongyle sp.+ Trichuris sp.) and group II (Strongyle sp.) are infected treated groups whereas group III (Amphistome sp. + Strongyle sp.) was untreated control group. The animals of group I and group II was treated with Neozide plus bolus @ 10 mg/kg b.wt. and Minthal bolus @ 7.5 mg/kg b.wt., respectively. The egg per gram of feces (EPG) and milk production (litres) were recorded pre-treatment and post-treatment (1, 2, 3 and 4 weeks). Post-treatment EPG (Mean \pm SE) in animals of group I and group II was reduced to zero which was maintained up to $4^{\text {th }}$ weeks. Post-treatment milk yield in animals of group I during $1^{\text {st }}, 2^{\text {nd }}, 3^{\text {rd }}$ and $4^{\text {th }}$ weeks were $0.83 \pm 0.16,0.88 \pm 0.15,0.92 \pm 0.16$ and $0.96 \pm 0.17$ litres, respectively while in group II post-treatment milk yield in animals during $1^{\text {st }}, 2^{\text {nd }}, 3^{\text {rd }}$ and $4^{\text {th }}$ weeks were $0.93 \pm 0.11,0.95 \pm 0.11,0.97 \pm 0.10$ and $1.00 \pm 0.10$, respectively. An increase of $24.67 \%$ and $25 \%$ milk production was recorded over a period of 4 weeks in animals of group I and group II, respectively. However, in group III (control), milk production was reduced significant $(\mathrm{P}<0.05)$ by $38.46 \%$ over a period of 4 weeks.
\end{abstract}

\section{HIGHLIGHTS}

(0 Study focused on impact of helminth infections on milk production in swamp buffaloes.

0 Helminth infections reduced milk production significantly.

Keywords: Gastrointestinal, Helminth, Milk, Impact, Swamp Buffalo

Livestock plays an important role in Indian economy and is an important subsector of Indian Agriculture. As per $20^{\text {th }}$ Livestock census (2019), the buffalo population of the country are 109.85 million, accounting 20.50\% of total livestock population (535.78 million). Majority of the small and marginal farmers depend on buffaloes for their livelihood as they also serve as an insurance against the risk of crop failure due to natural calamities (Sreedevi and Hafeez, 2014). Parasites of livestock cause diseases of major socioeconomic importance worldwide, responsible for financial loss and have a substantial impact on farm profitability (Roeber et al., 2013). In buffaloes high prevalence rate of helminths may be attributed to the swamp liking nature of the host (Banerjee, 1991) as marshy environment is suitable for development of several helminth species as well as snails (Waruiru et al., 1998). The economic losses are mainly due to subclinical effects which go unnoticed to the owner's. Subclinical infections are responsible for high morbidity and mortality in young animals and enormous production losses in adults. The economic losses occurs in terms of lowered fertility, reduced work capacity, involuntary culling, reduced feed

How to cite this article: Das, M. and Deka, D.K. (2021). Economic Impact of Gastrointestinal Helminth Infections on Milk Production in Swamp Buffalo. J. Anim. Res., 11(05): 831-836.

Source of Support: None; Conflict of Interest: None 
intake, low milk production, treatment cost and mortality (Raza et al., 2012). Generally, low level of G.I. parasitic infection is present in animals without causing much damage to the susceptible animals. But when the intensity i.e. egg per gram (EPG) faeces in infected animal is high then it is harmful for the animals and require immediate treatment. Therefore, the present study was designed to assess the economic impact of gastrointestinal helminth infections on milk production in swamp buffaloes of Guwahati, Assam.

\section{MATERIALS AND METHODS}

\section{Study area}

The present study was conducted in Guwahati, the capital city of the state of Assam, India that lies within the latitude of $26^{\circ} 11^{\prime} 0^{\prime \prime} \mathrm{N}$ and longitude $91^{\circ} 44^{\prime} 0^{\prime \prime} \mathrm{E}$. The city is situated on an undulating plain with varying altitudes of 49.5$55.5 \mathrm{~m}$ above mean sea level. The southern and eastern sides of the city are surrounded by hillocks.

\section{Study design}

The assessment of economic impact of gastrointestinal helminth infections on milk production was studied in naturally infected swamp buffalo cows by treating them with anthelmintics (Rahman and Samad, 2010). The selection criteria of animals included similar nutrition, no history of deworming, $3^{\text {rd }}-5^{\text {th }}$ lactation (mid lactation 3-6 months) and aged between 5-7 years. Selected animals was divided into three groups (I, II and III) on the basis of egg per gram of faeces (EPG) having 10 animals in each group. Animals of group I (Amphistome+Strongyle + Trichuris) and group II (Strongyle) was infected treated groups whereas group III (Amphistome + Strongyle) was untreated control group. The animals of group I and group II was treated with Neozide plus bolus (oxyclozanide and levamisole, @ 10 mg/kg b.wt.; Intas Pharmaceuticals Ltd.) and Minthal bolus (albendazole, @ $7.5 \mathrm{mg} / \mathrm{kg}$ b.wt; Alembic Pharmaceuticals Ltd.), respectively. The egg per gram (EPG) of faeces was counted pre-treatment and $1^{\text {st }}, 2^{\text {nd }}, 3^{\text {rd }}$ and $4^{\text {th }}$ weeks post-treatment (Solusby, 1982). Pre-treatment ( 0 day) and post-treatment $\left(1^{\text {st }}, 2^{\text {nd }}, 3^{\text {rd }}\right.$ and $4^{\text {th }}$ weeks) milk production (litres) records were recorded in order to calculate per animal per day increase in the quantity of milk yield. Increase or decrease in milk yield production was calculated using the following formula:

$$
C=A-B
$$

Where, $\mathrm{C}=$ Increase/decrease in milk yield (in litres)

$\mathrm{A}=$ Milk yield 4 weeks post-treatment (in litres)

$\mathrm{B}=$ Pre-treatment milk yield (in litres)

\section{Statistical analysis}

Data were statistically analyzed by Analysis of Variance (ANOVA) for significance using SPSS 15 version.

\section{RESULTS AND DISCUSSION}

The effects of anthelmintic treatment on pre-treatment and post-treatment EPG swamp buffalo are shown in Table 1. Pre-treatment EPG (Mean \pm SE) in animals of group I and group II are $650 \pm 34.96$ and $580 \pm 45.46$, respectively.

Table 1: Effect of anthelmintic treatment on mean EPG of buffalo

\begin{tabular}{|c|c|c|c|c|c|c|c|c|}
\hline \multirow{2}{*}{ Group } & \multirow{2}{*}{$\begin{array}{l}\text { No. of } \\
\text { animals }\end{array}$} & \multirow{2}{*}{$\begin{array}{l}\text { Anthelmintic } \\
\text { treatment }\end{array}$} & \multirow{2}{*}{$\begin{array}{l}\text { Pre-treatment } \\
\mathrm{EPG} \pm \mathrm{SE}\end{array}$} & \multicolumn{4}{|c|}{ Post-treatment EPG $($ Mean \pm SE $)$} & \multirow{2}{*}{$\begin{array}{l}\text { Total (Mean } \pm \\
\text { SE) }\end{array}$} \\
\hline & & & & 1st $^{\text {st }}$ eek & $2^{\text {nd }}$ week & $3^{\text {rd }}$ week & $4^{\text {th }}$ week & \\
\hline $\mathrm{I}$ & 10 & Neozide plus & $650^{\mathrm{abc}} \pm 34.96$ & $0.00^{\mathrm{d}}$ & $0.00^{\mathrm{d}}$ & $0.00^{\mathrm{d}}$ & $0.00^{\mathrm{d}}$ & $130^{\mathrm{b}} \pm 37.74$ \\
\hline II & 10 & Minthal & $580^{\mathrm{c}} \pm 45.46$ & $0.00^{\mathrm{d}}$ & $0.00^{\mathrm{d}}$ & $0.00^{\mathrm{d}}$ & $0.00^{\mathrm{d}}$ & $116^{\mathrm{b}} \pm 34.27$ \\
\hline III & 10 & Control & $605^{b c} \pm 41.13$ & $\begin{array}{l}585^{b c} \pm \\
44.75\end{array}$ & $\begin{array}{l}610^{b c} \pm \\
39.30\end{array}$ & $\begin{array}{l}665^{\mathrm{ab}} \pm \\
40.86\end{array}$ & $\begin{array}{l}710^{a} \pm \\
28.67\end{array}$ & $635^{\mathrm{a}} \pm 18.08$ \\
\hline \multicolumn{3}{|c|}{ Total $($ Mean \pm SE) } & $611.67^{\mathrm{a}} \pm 23.33$ & $\begin{array}{l}195^{\mathrm{c}} \pm \\
53.19\end{array}$ & $\begin{array}{l}203.33^{b c} \pm \\
54.87\end{array}$ & $\begin{array}{l}221.67^{b c} \pm \\
59.68\end{array}$ & $\begin{array}{l}236.67^{b} \pm \\
62.83\end{array}$ & $\begin{array}{l}293.67 \pm \\
26.68\end{array}$ \\
\hline
\end{tabular}

Means with different superscripts differ significantly $(\mathrm{P}<0.05)$. 
However, post-treatment EPG (Mean \pm SE) in animals of group I and group II was reduced to zero which was maintained up to $4^{\text {th }}$ weeks. However, the pre-treatment and post-treatment $\left(1^{\text {st }}-4^{\text {th }}\right.$ weeks $)$ EPG $($ Mean \pm SE) in animals of group III (control) were 605 \pm 41.13 , $585 \pm 44.75,610 \pm 39.30,665 \pm 40.86$ and $710 \pm 28.67$, respectively. ANOVA of anthelmintic treatments on EPG of buffalo (Table 2$)$ revealed significant effect $(\mathrm{P}<0.01)$ of anthelmintic treatment on EPG of animals over a defined period of time.

The effect of anthelmintic treatment on milk production was shown in Table 3. The pre-treatment average milk yield/ animal/day (litres) observed in animals of group I, II and III were $0.77 \pm 0.14,0.80 \pm 0.10$ and $0.78 \pm 0.04$, respectively. However, the post-treatment average milk yield/animal/ day (litres) was found to increase every week up to $4^{\text {th }}$ week in both the treated groups (I, II). The post-treatment milk yield recorded in animals of group I during $1^{\text {st }}, 2^{\text {nd }}$, $3^{\text {rd }}$ and $4^{\text {th }}$ weeks were $0.83 \pm 0.16,0.88 \pm 0.15,0.92 \pm 0.16$ and $0.96 \pm 0.17$ litres, respectively. The post-treatment milk yield recorded in animals of group II during $1^{\text {st }}, 2^{\text {nd }}$, $3^{\text {rd }}$ and $4^{\text {th }}$ weeks were $0.93 \pm 0.11,0.95 \pm 0.11,0.97 \pm 0.10$ and $1.00 \pm 0.10$, respectively. However, in untreated group III (control), milk yield recorded during $1^{\text {st }}, 2^{\text {nd }}, 3^{\text {rd }}$ and $4^{\text {th }}$ weeks were $0.71 \pm 0.04,0.62 \pm 0.04,0.55 \pm 0.04$ and $0.48 \pm 0.03$, respectively. Therefore, an increase of $24.67 \%$ and $25 \%$ milk production was recorded over a period of 4 weeks in animals of group I (amphistome + strongyle) and group II (strongyle), respectively. However, in group III (control), milk production was reduced by $38.46 \%$ over a period of 4 weeks. Statistically, the difference in the total milk production of group I, II and III was found to be significant $(\mathrm{P}<0.05)$. ANOVA revealed significant effect $(\mathrm{P}<0.01)$ of anthelmintic treatment and time on milk production in buffalo (Table 4). A net profit of ₹ 4.28 per animal was observed over a period of 4 weeks following anthelmintic treatment (Table 5). However, a loss of ₹ 75.60 per animal was observed in infected untreated

Table 2: ANOVA of anthelmintic treatment on EPG in buffalo

\begin{tabular}{|c|c|c|c|c|c|}
\hline Source & d.f. & Sum of Squares & Mean Square & F Ratio & Prob $>$ F \\
\hline Anthelmintic treatment & 2 & 8743033 & 4371517 & 1598.79 & $<.0001 * *$ \\
\hline Animal No. & 9 & 228150 & 25350 & 9.27 & $<.1105$ \\
\hline Animal No. $\times$ Anthelmintic treatment & 18 & 468300 & 26017 & 9.52 & $<.2132$ \\
\hline Time & 4 & 3823567 & 955892 & 349.60 & $<.0001 * *$ \\
\hline Anthelmintic treatment $\times$ Time & 8 & 2353133 & 294142 & 107.58 & $<.0001 * *$ \\
\hline Error & 108 & 295300 & 2734 & & \\
\hline C. Total & 149 & 15911483 & & & \\
\hline
\end{tabular}

$* * \mathrm{P}<0.01$.

Table 3: Effect of anthelmintic treatment on milk production of buffalo

\begin{tabular}{|c|c|c|c|c|c|c|c|c|c|}
\hline \multirow{2}{*}{ Group } & \multirow{2}{*}{$\begin{array}{l}\text { No. of } \\
\text { animals }\end{array}$} & \multirow{2}{*}{$\begin{array}{l}\text { Anthelmintic } \\
\text { treatment }\end{array}$} & \multirow{2}{*}{$\begin{array}{l}\text { Pre-treatment } \\
\text { milk production } \\
(\text { Litres) } \\
(\text { Mean } \pm \text { SE) }\end{array}$} & \multicolumn{4}{|c|}{$\begin{array}{l}\text { Post-treatment milk production (Litres) } \\
(\text { Mean } \pm \text { SE })\end{array}$} & \multirow{2}{*}{$\begin{array}{l}\text { - Total } \\
\text { (Mean } \pm \text { SE) }\end{array}$} & \multirow{2}{*}{$\begin{array}{l}\text { Percent Increase/ } \\
\text { Decrease in milk } \\
\text { production over } \\
\text { a period of } 4 \\
\text { weeks }\end{array}$} \\
\hline & & & & $1^{\text {st }}$ week & $2^{\text {nd }}$ week & $3^{\text {rd }}$ week & $4^{\text {th }}$ week & & \\
\hline I & 10 & Neozide plus & $0.77^{\mathrm{de}} \pm 0.14$ & $\begin{array}{l}0.83^{\mathrm{cd}} \pm \\
0.16\end{array}$ & $\begin{array}{l}0.88^{\text {bcd }} \pm \\
0.15\end{array}$ & $\begin{array}{l}0.92^{\mathrm{abc}} \pm \\
0.16\end{array}$ & $\begin{array}{l}0.96^{\mathrm{ab}} \pm \\
0.17\end{array}$ & $0.87^{b} \pm 0.07$ & $(+) 24.67$ \\
\hline II & 10 & Minthal & $0.80^{\mathrm{de}} \pm 0.10$ & $\begin{array}{l}0.93^{\mathrm{abc}} \pm \\
0.11\end{array}$ & $\begin{array}{l}0.95^{\mathrm{ab}} \pm \\
0.11\end{array}$ & $\begin{array}{l}0.97^{\mathrm{ab}} \pm \\
0.10\end{array}$ & $\begin{array}{l}1.00^{\mathrm{a}} \pm \\
0.10^{2}\end{array}$ & $0.93^{\mathrm{a}} \pm 0.05$ & (+) 25.00 \\
\hline III & 10 & Control & $0.78^{\mathrm{de}} \pm 0.04$ & $\begin{array}{l}0.71^{\mathrm{ef}} \pm \\
0.04\end{array}$ & $\begin{array}{l}0.62^{\mathrm{fg}} \pm \\
0.04\end{array}$ & $\begin{array}{l}0.55^{\mathrm{gh}} \pm \\
0.04^{4}\end{array}$ & $\begin{array}{l}0.48^{\mathrm{h}} \pm \\
0.03\end{array}$ & $0.63^{c} \pm 0.02$ & (-) 38.46 \\
\hline Total (N & $\mathrm{an} \pm \mathrm{SE})$ & & $0.78^{a} \pm 0.06$ & $\begin{array}{l}0.82^{\mathrm{a}} \pm \\
0.06^{2}\end{array}$ & $\begin{array}{l}0.82^{\mathrm{a}} \pm \\
0.07\end{array}$ & $\begin{array}{l}0.81^{\mathrm{a}} \pm \\
0.07\end{array}$ & $\begin{array}{l}0.81^{\mathrm{a}} \pm \\
0.08\end{array}$ & $0.81 \pm 0.03$ & \\
\hline
\end{tabular}

Means with different superscripts differ significantly $(\mathrm{P}<0.05)$. 
Table 4: ANOVA of anthelmintic treatment on milk production in buffalo

\begin{tabular}{llllll}
\hline Source & d.f. & Sum of Squares & Mean Square & F Ratio & Prob $>$ F \\
\hline Anthelmintic treatment & 2 & 2.586633 & 1.29 & 234.01 & $<.0001^{* *}$ \\
Animal No. & 9 & 5.415067 & 0.60 & 108.86 & $<.2331$ \\
Animal No. $\times$ Anthelmintic treatment & 18 & 10.475033 & 0.58 & 105.29 & $<.1120$ \\
Time & 4 & 0.028567 & 0.0071 & 1.29 & 0.2777 \\
Anthelmintic treatment $\times$ Time & 8 & 1.021533 & 0.13 & 23.10 & $<.0001^{* *}$ \\
Error & 108 & 0.596900 & 0.0055 & & \\
C. Total & 149 & 20.123733 & & & \\
\hline
\end{tabular}

$* * \mathrm{P}<0.01$

Table 5: Economic impact of anthelmintic treatment on milk yield of buffalo

\begin{tabular}{|c|c|c|c|c|c|c|c|}
\hline \multirow[b]{2}{*}{ Group } & \multirow[b]{2}{*}{$\begin{array}{l}\text { No. of } \\
\text { animals }\end{array}$} & \multicolumn{5}{|c|}{ Total milk yield (Litres) } & \multirow{2}{*}{$\begin{array}{l}\text { Total Increase / } \\
\text { Decrease in milk } \\
\text { production (Ltrs) over } \\
\text { a period of } 4 \text { weeks }\end{array}$} \\
\hline & & $\begin{array}{l}\text { One week pre- } \\
\text { treatment }\end{array}$ & $\begin{array}{l}1^{\text {st }} \\
\text { week }\end{array}$ & $\begin{array}{l}2^{\text {nd }} \\
\text { week }\end{array}$ & $\begin{array}{l}3^{\text {rd }} \\
\text { week }\end{array}$ & $\begin{array}{l}4^{\text {th }} \\
\text { week }\end{array}$ & \\
\hline $\begin{array}{l}\text { (A) Infected } \\
\text { Treated (I, II) }\end{array}$ & 20 & 109.55 & 122.85 & 128.10 & 132.30 & 137.20 & $(+) 27.65$ \\
\hline $\begin{array}{l}\text { (B) Infected } \\
\text { Untreated (III) }\end{array}$ & 10 & 54.60 & 49.35 & 43.40 & 38.15 & 33.60 & (-) 21.00 \\
\hline Income from increased/decreased milk production & & & & & \multicolumn{2}{|c|}{ Group A } & Group B \\
\hline (₹ 37.0/litre) & & & & & \multicolumn{2}{|c|}{$(+) 1023.00$} & $(-) 756.00$ \\
\hline Expenditure on anthelmintics $(₹)$ & & & & & \multicolumn{2}{|c|}{$(-) 937.50$} & - \\
\hline Net Profit/Loss* (₹) & & & & & \multicolumn{2}{|c|}{$(+) 85.50$} & $(-) 756.00$ \\
\hline Net Profit/Loss/Animal (₹) & & & & & \multicolumn{2}{|c|}{$(+) 4.28$} & $(-) 75.60$ \\
\hline
\end{tabular}

animals over a period of 4 weeks. In the present study, an average increase of $0.96 \pm 0.17$ litre and $1.00 \pm 0.10$ litre of milk yield was observed at the end of $4^{\text {th }}$ week in anthelmintic treated groups.

The present findings are in agreement with the finding of Kumar and Pachauri (1989) who observed 13.8\% increase in average milk yield at the end of $4^{\text {th }}$ week in F. gigantica infected buffaloes following treatment with albendazole. Similarly, Sharma (2001) observed an increase in milk yield (1.20 litre/day/buffalo) after treatment with triclabendazole in Fasciola sp./ Paramphistomum sp. infected buffaloes. Sanyal and Singh (1995) stated that long-term strategic low level administration of fenbendazole incorporated medicated urea molasses blocks could effectively remove adult parasites and prevent larval establishment in buffalo. Milk output in treated buffalo was $(\mathrm{P}<0.01)$ from 45 days onward with a net gain of 1.20 litre per day. Rahman and
Samad (2010) also observed an average increase in milk yield (0.32 litre/day/animal) of Red Chittagong cattle infected with subclinical gastro-intestinal parasitosis following anthelmintic treatment. Gains in milk yield may be attributed to improvement in feed intake and feed conversion ratio after anthelmintic treatment (Oakley et al., 1979). Absorption of proteins, lipids, carbohydrates, vitamins and minerals has been reported to be altered by endoparasites resulting in the deficiency of these elements (Lee et al., 1999; Saleh et al., 2007). Deficiency of trace elements results in weight and yield losses (Herd, 1993). Moreover, Odoi et al. (2008) observed that under congenial environmental condition, the parasitic load increases and thereby causes significant economic loss in terms of reduction of daily milk yield. According to Thapa Shrestha et al. (2020), the average milk yield (litre/day/ cow) significantly increased by 1.06 litres in levamisole 
hydrochloride-oxyclozanide treated buffaloes. The lactose and solid percentage increased significantly in buffaloes $(\mathrm{P}=0.002$ and $\mathrm{P}=0.028)$ after deworming. Similarly, Athar et al. (2011) observed a significant decrease in fecal egg counts (FEC) in oxyclozanide medicated buffaloes on day 14 post-treatment. An average daily increase of 0.89 liters of milk and $0.42 \%$ fat per buffalo was observed in oxyclozanide medicated buffaloes. They observed that the economic value of reduced production in infected buffaloes was US\$ 0.41 per animal per day. Similarly, Verschave et al. (2014) observed that eprinomectin treatment around calving increased daily milk yield of $0.97( \pm 0.41) \mathrm{kg}$ up to 274 days. According to Perri et al. (2011) milk production lowered significantly in animals with FEC >10 EPG. Charlier et al. (2012), observed that the efficient nematode control could result in an important return on investment with expected benefits for an average herd between $\$ 15$ and $\$ 63 /$ lactation. Thus, it can be concluded that G.I. helminth infections have direct impact on milk production and regular anthelmintic medication required for profitable farming. But it is important to keep in mind that parasites become resistant due to repeated use of similar types of anthelmintics over a considerable period of time, and thus it is mandatory to switch over to the alternative anthelmintic to control parasites effectively.

\section{CONCLUSION}

The present study revealed that the gastrointestinal helminth infections have direct impact on milk production in the swamp buffaloes. Effective and regular anthelmintic medication required to prevent production loss as well as for profitable farming.

\section{ACKNOWLEDGMENTS}

The authors are grateful to the Dean, Faculty of Veterinary Science and Director Post Graduate Studies, Assam Agricultural University, Khanapara, Guwahati, Assam for providing financial assistance and necessary facilities to conduct the research work.

\section{REFERENCES}

Athar, L.A., Khan, M.N., Sajid, M.S., Rehman, T.U. and Khan, I.A. 2011. Cost benefits analysis of anthelmintic treatment of cattle and buffaloes. Pak. Vet. J., 31(2): 149-152.
Banerjee, G.C. 1991. A text book of Animal Husbandry. $7^{\text {th }}$ ed, Oxford \& IBH Publishing Co. Pvt. Ltd., New Delhi, India, pp. 102-104.

Charlier, J., Levecke, B., Devleesschauwer, B., Vercruysse, J., Hogeveen, H. 2012. The economic effects of whole-herd versus selective anthelmintic treatment strategies in dairy cows. J. Dar. Sci., 95: 2977-2987.

Herd, R.P. 1993. Nematode infections in cattle, sheep, goat and swine. In: Current Veterinary Therapy; Howard JL (ed), $3^{\text {rd }}$ Ed. WB Saunders Company, Philadelphia, pp. 750.

Kumar, P. and Pachauri, S.P. 1989. Efficacy of albendazole against Fasciola gigantica infection in buffaloes with particular reference to milk production. J. Vet. Parasitol., 3: 35-39.

Lee, J., Masters, D.G., White, C.L., Grace, N.D. and Judson, G.J. 1999. Current issues in trace element nutrition of grazing livestock in Australia and New Zealand. Australian J. Agricul. Res., 50: 1341-1364.

Livestock Census. 2019. 20 $0^{\text {th }}$ Livestock Census. Department of Animal Husbandry, Dairying and Fisheries, Ministry of Agriculture, Government of India.

Oakley, G.A., Owen, B. and Knapp, N.H. 1979. Production effects of subclinical liver fluke infection in growing dairy heifers. Vet. Rec., 104: 503-507.

Odoi, A., Gathuma, J.M., Gachuri, C.K. and Omore, A. 2008. Feeding practices and effects of gastrointestinal parasite infections on live weight gain of small ruminants in smallholders mixed farms of Kenya. Res. Vet. Sci., 84: 185193.

Perri, A.F., Mejia, M.E., Licoff, N., Lazaro, L., Miglierina, M., Ornstein, A., Becu-Villalobos, D. and Lacau-Mengido, I.M. 2011. Gastrointestinal parasites presence during the peripartum decreases total milk production in grazing dairy Holstein cows. Vet. Parasitol., 178: 311-318.

Rahman, M.M. and Samad, M.A. 2010. Prevalence of subclinical gastro-intestinal parasitosis and their effects on milk production with therapeutic management in Red Chittagong cattle. Bangladesh J. Vet. Med., 8(1): 11-16.

Raza, M.A., Murtaza, S., Bachaya, H.A., Arshad, H.M., Naeem, M. and Kazmi, H.F. 2012. Predominance of gastrointestinal helminthiasis in Ovisaries (sheep) at the vicinity of Jatoi, Pakistan Science. Intern. J. Sci. Res. Pub., 24: 289-292.

Roeber, F., Jex, A.R. and Gasser, R.B. 2013. Impact of gastrointestinal parasitic nematodes of sheep, and the role of advanced molecular tools for exploring epidemiology and drug resistance - an Australian perspective. Paras. Vec., 6: 153.

Saleh, M.A., El-Ela, A.A. and Osman, F.A. 2007. Trace elements variation in blood serum of sheep suffering from internal 
parasites in recently reclaimed areas (Darb Al-Arbaiyn) in the West Egyptian desert. Assiut Vet. Med. J., 53: 181-194.

Soulsby, E.J.L. 1982. Helminths, Arthropods and Protozoa of Domesticated Animals. $7^{\text {th }}$ Edn., ELBS and Baillere Tindal, London.

Sanyal, P.K. and Singh, D.K. 1995. Administration of fenbendazole in urea molasses block to dairy buffaloes in India. Tropical Anim. Hlth. Prod., 27: 186-190.

Sharma, R.K. 2001. Studies on helminthic status, therapeutic control and their impact on milk production in dairy animals in some areas of Jharkhand. M.V.Sc. Thesis, Bihar Agricultural University, Ranchi.

Sreedevi, C. and Hafeez, M.D. 2014. Prevalance of gastrointestinal parasites in buffaloes (Bubalus bubalis) in and around Tirupati, India. J. Buff. Bull., 33(3): 251-255.
Thapa Shrestha, U., Adhikari, N., Kafle, S., Shrestha, N., Banjara, M.R., Steneroden, K., Bowen, R., Rijal, K.R., Adhikari, B. and Ghimire, P. 2020. Effect of deworming on milk production in dairy cattle and buffaloes infected with gastrointestinal parasites in the Kavrepalanchowk district of central Nepal. Vet. Rec. Open, 7: e000380.

Verschave, S.H., Vercruysse, J., Forbes, A., Opsomer, G., Hosten, M., Duchateau, L. and Charlier, J. 2014. NonInvasive indicators associated with the milk yield response after anthelmintic treatment at calving in dairy cows. $B M C$ Vet. Res., 10: 264.

Waruiru, R.M., Munyua, W.K., Thamsborg, S.M., Nansen, P., Bogh, H.O. and Gathuma, J.M. 1998. Development and survival of infective larvae of gastrointestinal nematodes of cattle on pasture in central Kenya. Vet. Res. Commun., 22: 315-323. 